\title{
Digital Archiving for Archaeology: the state of the art in Argentina
}

\author{
Andrés D. Izeta and Roxana Cattáneo
}

\section{Summary}

This article discusses the state-of-the art of digital archives for archaeological research in Argentina. It also presents and characterises the national and international legal framework and the role played by funding agencies and professional bodies in archaeological practice. In addition, it reports how legal corpora regulate the impact on the management of archaeological digital data. Research infrastructures available at the national level are described, such as the Suquía, an institutional digital archive devoted to archaeology since 2016. Finally, we make a general evaluation of the status quo of research infrastructures mostly concerned with preserving and disseminating data from archaeological research at the national level.

\section{Introduction}

Archaeology in Argentina has a tradition of more than 150 years. During this period, as in any scientific discipline, various theoretical frameworks have been proposed to address local, regional and global problems. Several authors have established a sequence in which local archaeology developed (e.g. Fernández 1979; Politis 1992), identifying a first stage in the 19th century represented by naturalists interested in fossil or archaeological records. In most cases they were professionals working in other scientific disciplines and avocational archaeologists. However, from the 1880s, on the basis of public policies and legislation aimed at protecting the archaeological and palaeontological heritage, chairs and positions were established within university museums, allowing the inclusion of professional archaeologists (e.g. Fernández 1979; Politis 1992; Politis and Curtoni 2011). Towards the beginning of the 20th century, these institutions were the ones dedicated to the study of material culture from national archaeological sites. The Museum of La Plata (which would be one venue for the creation of the National University of La Plata) and the Ethnographic Museum of the University of Buenos Aires carried out expeditions in various regions, such as the Argentinian Northwest, where archaeological remains of complex societies were found, 
and the Pampa or Patagonia, where 10,000 years of occupation by hunter-gatherer societies were studied. Note that, during that period, archaeological practice focused on the study of pre-Hispanic contexts (prior to the Spanish colonisation starting $1500 \mathrm{CE}$ ), thus involving the archaeological heritage of indigenous communities that occupied and occupy the current Argentinian territory. The development of historical archaeology did not take place until well into the 20th century.

Around the 1930s, archaeology in Argentina was institutionalised through the establishment of academic positions and new research institutes in the provinces (e.g. Guber et al. 2007). In 1958, a milestone was reached for the development of this discipline: a state-owned, non-university institution, CONICET (National Scientific and Technological Research Council), was established based on the French research system (e.g. Politis and Curtoni 2011). Ultimately, this institution came to house the largest number of professional archaeologists across the country. Since the 1960s, other organisations at different levels of state management, such as provinces and municipalities, joined the structural framework of the heritage sector. The latter gave rise to controlling bodies for professional practice and support for local archaeological museums. This applies to another state institution: the National Institute of Anthropology and Latin-American Thought (INAPL), which later in the 2000s became the regulating body for the archaeological and heritage sector at the national level according to Law $\underline{25743}$ (2003).

During the 1990s, the federal government promoted the construction of large infrastructure works and archaeological impact studies were implemented for the first time (e.g. Aschero 1998; Ratto 1998; 2010). Although such studies had been linked in previous decades to the building of hydroelectric dams, this was an extraordinary intervention (Endere and Rolandi 2007). However, by the end of the 20th century this practice became increasingly common, extending not only to hydroelectric facilities but also to the installation of electric transmission lines, wind farms, mining, roads and any other large infrastructure developments financed by the state. Later, other types of contract archaeology were implemented at a more local and specific level in relation to excavation in urban environments prior to the construction of new buildings (Izeta et al. 2017).

Other institutional actors, besides the federal administration, are provincial and municipal government levels that can include archaeologists within their structures. The role played by archaeologists within these organisations differs, in most cases, because heritage management activities become more important. To complete the archaeological practice scenario in Argentina, in recent years private organisations have increased their funding of some archaeological work, mostly related to the digitisation of archaeological collections.

Today, CONICET is the main Argentine government agency for scientific and technical research with the largest budget and highest number of employees. It supervises and coordinates most research done in universities and institutes. CONICET comprises $c$. 300 archaeologists, 25 assistants and 200 scholarship holders. Other professional archaeologists work in federal, provincial and local government offices and others still in Cultural Resource Management. Every three years the National Archaeological Congress holds a session with around 1000 participants. Therefore, we can take this as the average number of archaeologists currently undertaking research in Argentina. This number is similar to that provided by the Argentine Association of Professional Archaeologists (G. Barrientos pers. comm., February 2019). 


\section{Archaeological-themed Physical and Digital Documentary Archives}

All the work performed by the above-mentioned archaeologists generates different types of data that are transferred to various media. Primary data usually remain in the hands of researchers, whereas research reports are provided to funding organisations such as CONICET, universities, museums, provinces and municipalities or private companies. A large part of these results are published in national and international science journals, books or as monographs.

However, vast amounts of data are not shared among researchers and get lost. This situation encouraged science and technology funding agencies to call for the passing of new legislation that envisaged the mandatory deposit of primary data in institutional digital repositories (Law 26899, 2013). In brief, it is now mandatory for archaeologists who received public research funds to submit the primary data to institutional open access repositories.

In recent years, data on the management of archaeological organisations (e.g. museums) and researchers' (physical) documents have been integrated into institutional archives. For example, the Ethnographic Museum Archive (University of Buenos Aires) was established by the end of the 1980s (Pegoraro and Spoliansky 2013); the Historical Archive of the Museum of La Plata (National University of La Plata) was created in 1999; the Museum of Anthropology Archive (National University of Córdoba) was developed in 2001, all containing documentary material. They have also received donations of documentary collections from researchers such as those belonging to Alberto Rex González, physically housed at the Ethnographic Museum of the UBA and digitally stored in the DILA Archive, or to Jorge von Hauenschild and Aníbal Montes, deposited at the Anthropology Museum and digitally available in the Digital Repository of the National University of Córdoba and the Suquía Repository; Izeta et al. 2013).

Argentina has a long tradition of creating archives on disciplines within the social and human sciences (e.g. Fernández 1979; Farro 2013). However, at the federal level, modern legislation on this matter can be tracked to the 1960s when Law 15930 was approved, defining the functions of the National General Archive (Esteva et al. 2018).

At these institutions, specialised personnel handle and manage physical archives and documents, besides guaranteeing their long-term preservation. Yet, as seen above, though archaeologically orientated archives have developed over the last 30 years, these kinds of infrastructures are still scarce throughout the country.

If we consider how many of these physical archives have been developed into digital repositories the scene is by no means different. Public universities have received no specific funding for creating their own archaeology repositories. However, in the last ten years, CONICET, in conjunction with the Williams and Bunge \& Born Foundations, has been funding initiatives directed to the digitisation of archaeological collections. This has resulted in a growing interest in public and private funding organisations in transforming analogue to digital data and making them publicly available. However, so far, only one action has been implemented: The Suquía institutional repository of the Digital Archaeology Program of the Institute of Anthropology of Córdoba (an organisation of 
double affiliation: CONICET and the National University of Córdoba). A lot of work still needs to be done on the enhancement and dissemination of these e-infrastructures. In this sense, a national network called RADAR, Red Argentina de Arqueología Digital (Digital Archaeology Argentinian Network), created in 2018, groups professional archaeologists, librarians and IT specialists to fulfil this particular aim (Izeta and Cattáneo 2019).

\section{Other Current Legislation and Policy Guidelines}

The legislation affecting archaeological practice and, ultimately, the digital archive of data in Argentina is varied. Therefore, we will divide this section into three parts. First, international and national legislation. Second, legislation related to the institutions that finance science and technology. Third, the bodies and codes that guide professional practice.

\subsection{National and international laws}

A series of laws have had a major influence on archaeological practice relating to aboriginal peoples' material culture. Here, international treaties such as the ILO Convention 169 (C169 1989), the National Constitution (Article 75, paragraph 17, 1994) and Law 25517 (2001) allow archaeological research to be conducted in regions inhabited by indigenous communities only with their consent. To do so, some agreements need to be held, such as mutual agreements or FPIC protocols (free, prior and informed consent).

Argentinian Acts in force regulate and delimit some aspects of archaeological practice. In 2003, Law 25743 (Protection of Archaeological and Paleontological Heritage) was enacted, defining 'archaeological heritage', creating national regulatory structures and developing a national registry of archaeological sites and collections (e.g. Endere and Rolandi 2007). Provinces and municipalities also restrict archaeological research through their provincial constitutions (e.g. Constitution of Córdoba province, Art. 65), laws and decrees. Some municipalities have also enforced local bye-laws in relation to archaeological heritage, which, eventually, shapes the generation of archaeological data.

In 2013, the Argentine National Law on Digital Institutional Open Access Repositories was enacted (Law 26899, 2013). With this tool, the development of open access institutional digital repositories was prescribed as mandatory in those organisations that receive funding from the national state. The data derived from projects and from the work of researchers, professors and students (graduate and postgraduate level) must be housed in such digital repositories. This law also compels researchers to present a data management plan in accordance with the results expected for each project financed with public funds. It also requires that repositories comply with international standards that allow interoperability and unrestricted open access, thus adhering to the FAIR principles (Wilkinson et al. 2016). 


\subsection{Funding bodies}

Despite having a body of legislation on the creation of archaeological data and the deposit and catalogue of physical objects, there is still no consensus among funding agencies as to how digital data resulting from projects will be treated. However, since 2017, CONICET has established that a data management plan is compulsory only if researchers ask for a grant. This has allowed researchers, for the first time in the country, to plan what will be done with the digital data produced during the development and implementation of a research project. The data management plan has been adapted from the Digital Curation Centre (DCC) proposal (Actis and Carlino 2017). In the last CONICET and the Williams Foundation call for funding for the digitisation of archaeological collections, the need for a standardised set of metadata and a digital data management plan has been acknowledged. Other national and provincial funding agencies do not yet specify any requirement to deposit data generated in digital archives (e.g. Fund for Scientific and Technological Research -FONCyT-, Provincial States and National Public Universities).

\subsection{Professional bodies}

In Argentina, there are national and provincial organisations that bring together professional archaeologists. The Argentine Society of Anthropology is one of the oldest societies that include archaeologists. The Argentine Association of Professional Archaeologists forms a representative body regulating and supervising professional practice. Its interests also include the fostering of steps that lead to the preservation and improvement of archaeological heritage, encouraging the circulation of research results not only in national and international academic spheres but also to the general public. 


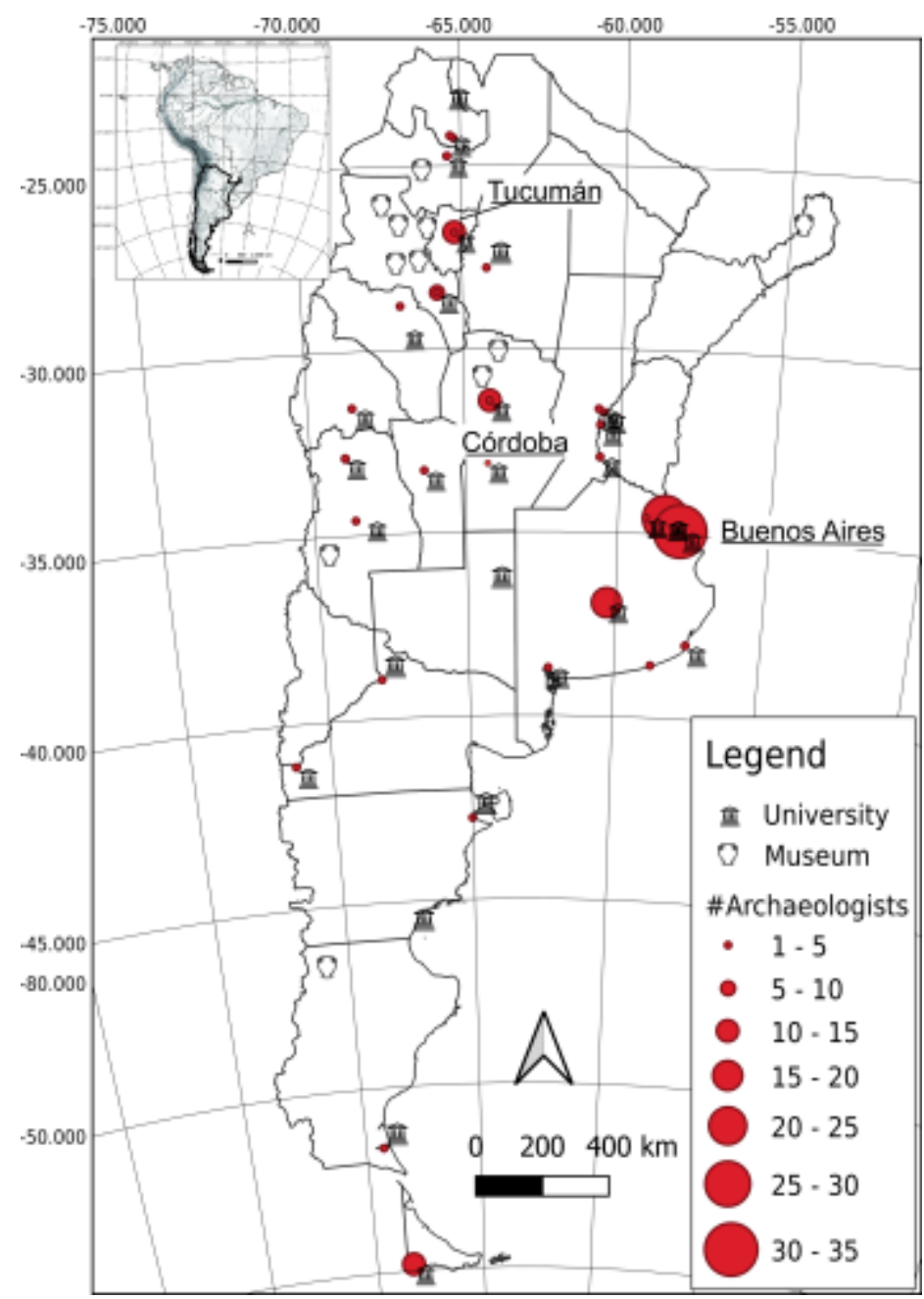

Figure 1: Argentinian archaeology at a glance. Location of archaeological academic centres showing frequency of professionals. Data retrieved on 24 October 2020, from https://www.conicet.gov.ar/new scp/advancedsearch.php

At the provincial level, the Professional Council of Archaeologists of Tucumán, CPAT, (Figure 1) brings together archaeologists who work in the territory of that province (Maloberti et al. 2019). Only AAPRA and CPAT offer a legal framework that can be related to data archiving. For instance, AAPRA in its Code of Ethics states: 'The results of the investigations must be made known to the public in a reasonable period and in as many areas as possible' (Asociación de Arqueólogos Profesionales de la República Argentina 2010, Article 16). While CPAT defines, in its statute, that 'Archaeology professionals must consider and plan the physical destination of the archaeological materials recovered and the scientific records made from them, the result of their research and/or management activities, ensuring their durability and adequate conservation. Likewise, accessibility to them must be guaranteed, complying with legislation, intellectual property and publication rights in force' (Colegio de Profesionales en Arqueología de la Provincia de Tucumán 2010, Article 17). 


\section{Repositories and Archaeological Digital Objects}

The science management model in Argentina is based on public funds. According to Law 25467 (2001, Article 5, subsection b), the state is responsible for financing 'the significant part of the knowledge creation activity under criteria of excellence'. Article 22 establishes that, at the national level, funding will be public, and provinces are invited to follow suit with similar financial amounts. Private companies, institutions and nongovernmental organisations can also finance science and technology. Also, public or private resources originating abroad can fund Argentinian science. In this sense, the model that prevails is that of financial contribution by the state. This means that digital files are developed and kept by the structure of the state. Computer systems, personnel and supplies are supported by state-owned science and technical institutions. This implies a cost for the state, but not for archaeologists, so they can upload 'for free' their data in these digital archives.

At present, digital e-research infrastructures are being developed in Argentina in association with national universities or other national scientific organisations. They usually host publications or grey literature, although graduate and postgraduate theses and dissertations are among the most commonly found items. Despite this, since 2016, Suquía is the only infrastructure that has, at a national level, other types of digital objects related to archaeology (Izeta and Cattáneo 2019).

\section{Archaeological Practice and Digital Data}

Much information produced by archaeologists through professional practice is incorporated into the usual channels of public documents, making them subject to the regulations of the National Public Administration (or provincial, or municipal regulations). This means that documents have low visibility, hampering access and retrieval (Esteva et al. 2018). Archaeologists, when asked, archive their data, particularly grey literature, with administrative public offices.

Since this information is subject to current regulations, it is liable to be destroyed within ten years. For this reason, information can be lost if actions are not taken regarding this problem.

\section{Today and the Near Future}

Undoubtedly, the legal framework in which Argentine archaeology has developed (Figure 2) and its growing research infrastructure will allow, in the short term, open access to an extensive amount of archaeological information. The National Network of Digital Archaeology, created in 2018 (Izeta and Cattáneo 2019), has paved the way so that many institutions learn about the digital archive of archaeological data. The implementation of harvesters such as SIU-BDU2 or the recent e- 
infrastructure DACyTAr has also allowed the collection of information on archaeological issues.

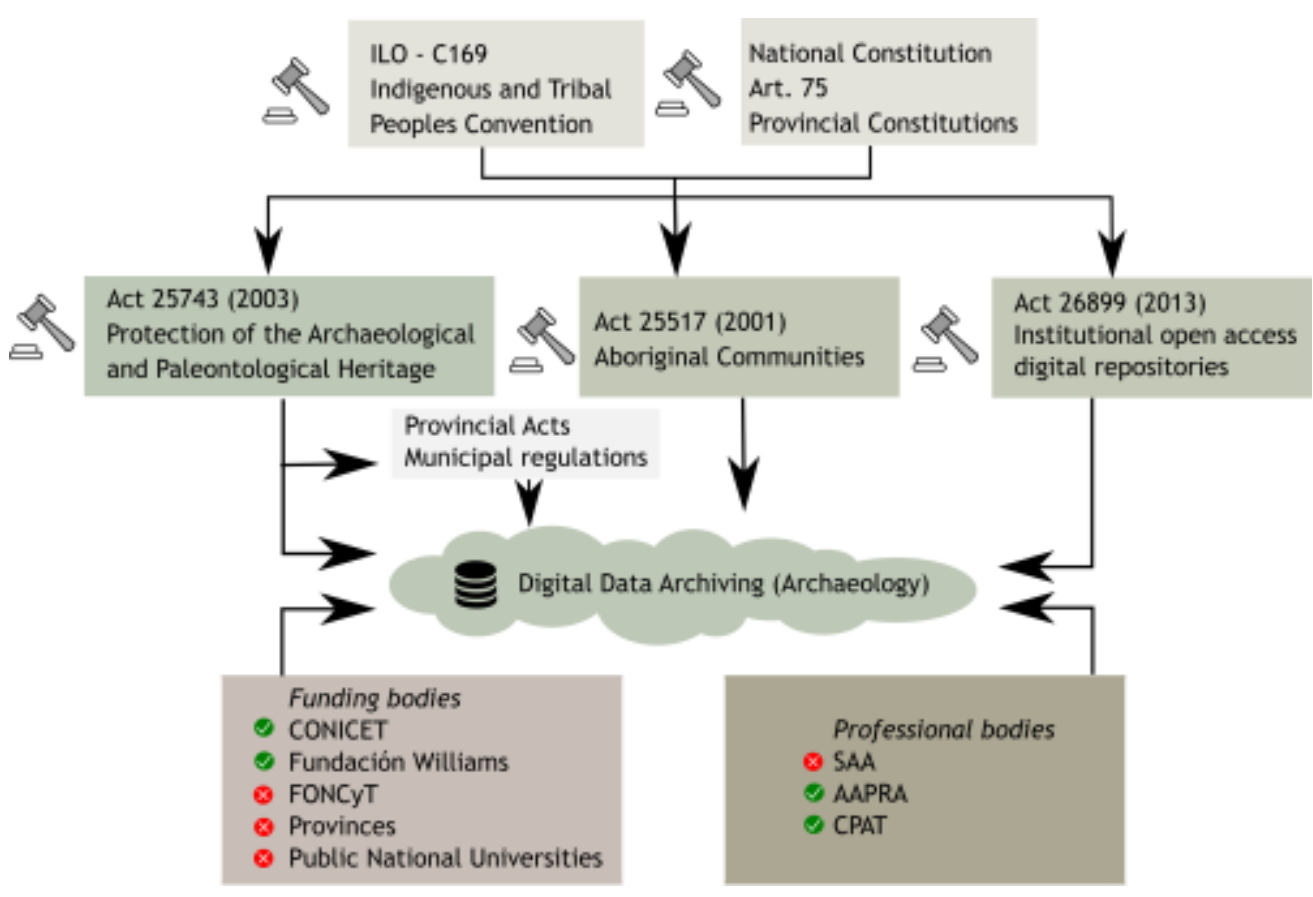

Figure 2:

Argentinian archaeological professional practice and the legal framework for digital data

This, together with the support of state organisations, NGOs and international projects such as ARIADNEPlus and SEADDA, undoubtedly foretells a promising future for the development of digital archives in archaeology. Finally, the availability of digital data and archives is expected to affect archaeological practice in a positive way, both at the local and global level.

\section{Acknowledgements}

We are grateful to Julian Richards for inviting us to participate as international observers in SEADDA (COST Action SEADDA -CA18128-, funded by Horizon 2020 Framework Program of the European Union) and international partners in ARIADNEPlus (H2020 Program, Contract No. H2020-INFRAIA-2018-1-823914). Both projects offered new insights into the ways digital archiving it is applied to archaeological data worldwide. This paper offers results from the Proyecto integral de investigación, preservación y transferencia del patrimonio', Instituto de Antropología de Córdoba, UNC-CONICET. Project PUE 22920160100024CO (Andrés Izeta, director). Carolina Mosconi (IDACOR CONICET/Universidad Nacional de Córdoba) helped with the English translation from the original draft in Spanish.

Actis, G. and Carlino, L. 2017 'Plan de Gestión de Datos en CONICET: análisis, experiencia y desafíos', VII Conferencia Internacional sobre Bibliotecas y Repositorios Digitales de América Latina (BIREDIAL-ISTEC'17) y XII Simposio Internacional de Biblioteca Digitales (SIBD'17), 215-31. http://sedici.unlp.edu.ar/handle/10915/63588 
Aschero, C.A. 1998 'Arqueología y situaciones de impacto: Reflexiones sobre el caso Tafí', Mundo de Antes 1(1), 15-

19. http://www.mundodeantes.org.ar/pdf/revista1//2\%20Ensayo\%20de\%20opinion.pdf

Asociación de Arqueólogos Profesionales de la República Argentina 2010 Código de Ética Profesional. http://www.aapra.org.ar/wp-content/uploads/2019/06/AAPRAC\%C3\%B3digo-de-\%C3\%89tica-Profesional.pdf

Colegio de Profesionales en Arqueología de la Provincia de Tucumán (Association of Professionals in Archaeology of the Province of Tucumán) 2010 Código de

Ética. https://drive.google.com/file/d/0BwanFOg7R4PVMGQ5MXVwVDdLQ3c/view [Last accessed: 7 October 2020].

Constitución de la Nación Argentina 1994 Senado y Cámara de Diputados de la Nación Argentina http://servicios.infoleg.gob.ar/infoleglnternet/anexos/0-

4999/804/norma.htm [Last accessed: 7 October 2020].

DILA Archive 2020 Laboratorio de Documentación e Investigación en Lingüística y Antropología (DILA), Área de Investigación del CAICYT - CONICET. http://www.caicytconicet.gov.ar/dila/collections/show/1 [Last accessed: 7 October 2020].

Endere, M. L. and Rolandi, D. 2007 'Legislación y gestión del patrimonio arqueológico. Breve reseña de lo acontecido en los últimos 70 años', Relaciones de la Sociedad Argentina de Antropología 32(1), 33-54. http://www.saantropologia.com.ar/wpcontent/uploads/2015/01/Relaciones\%2032/02\%20Endere-Rolandi.pdf

Esteva, M., Bongiovani, P.C., Frid, C., della Paolera, G., Uviña, R.F., Westberg, N., Zimmerman, E. and Gómez, J. 2018 Diagnóstico y prospectiva sobre la situación de la documentación histórica en Argentina, Subsecretaría de Evaluación Institucional. Secretaría de Articulación Científico-

Tecnológica. https://www.argentina.gob.ar/sites/default/files/documentacion historica.pd f

Farro, M. 2013 'Esas redes que la razón ignora. Archivos y colecciones en la 'biografía' institucional del Museo de La Plata', Revista Electrónica de Fuentes y Archivos 4(4), 7684. https://refa.org.ar/file.php?tipo=Contenido\&id=92

Fernández, J. 1979 'Historia de la arqueología argentina', Anales de Arqueología y Etnología 34-35, 1-320.

Guber, R., Bonnin, M. and Laguens, A. 2007 'Tejedoras, topos y partisanos. Prácticas y nociones acerca del trabajo de campo en la Arqueología y la Antropología Social en la Argentina', Relaciones de la Sociedad Argentina de Antropología 32, 381 -

406. http://sedici.unlp.edu.ar/handle/10915/21047

International Labour Organization 1989 United Nations. C169 - Indigenous and Tribal Peoples Convention, 1989 (No.

169). https://www.ilo.org/dyn/normlex/en/f?p=NORMLEXPUB:12100:0::NO::P12100 IN STRUMENT ID:312314 [Last accessed: 7 October 2020]. 
Izeta, A. and Cattáneo, R. 2019 'Archaeological digital repositories: fostering networks from the Global South' in F. Nicolucci and J. Richards (eds) The Ariadne Impact, Budapest: Archaeolingua. 163-74. https://doi.org/10.5281/zenodo.3476712

Izeta, A., Mateo, S. and Lencinas, V. 2013 'Digitalización del Fondo Documental Aníbal Montes (Museo de Antropología, FFyH, UNC): Práctica interdisciplinaria' in IV Encuentro de Museos Universitarios del Mercosur I Encuentro de Museos Universitarios Latinoamericanos y del Caribe, Santa Fe: Museo Histórico UNL Universidad Nacional del Litoral. https://issuu.com/museosuniversitarios/docs/libro de resumenes 2013/3

Izeta, A., Pautassi, E.A., Cattáneo, R., Robledo, A.I., Caminoa, J.M., Mignino, J. and Prado, I.E. 2017 Arqueología urbana en el área central de la ciudad de Córdoba, Argentina: Excavaciones en la sede corporativa del Banco de la Provincia de Córdoba (2014-2016), South American Archaeology Series 29, Oxford :

Archaeopress. https://suquia.ffyh.unc.edu.ar/handle/suquia/14893

Law 25467, 2001 Honorable Congreso de la Nación Argentina. Ley de Ciencia, Tecnología e Innovación. http://servicios.infoleg.gob.ar/infoleglnternet/anexos/6500069999/69045/norma.htm [Last accessed: 7 October 2020].

Law 25517, 2001 Honorable Congreso de la Nación Argentina. Comunidades indígenas. http://servicios.infoleg.gob.ar/infoleglnternet/anexos/7000074999/70944/norma.htm [Last accessed: 7 October 2020].

Law 25743, 2003 Honorable Congreso de la Nación Argentina. Protección del patrimonio arqueológico $y$ paleontológico. http://servicios.infoleg.gob.ar/infoleglnternet/anexos/8500089999/86356/norma.htm [Last accessed: 7 October 2020].

Law 26899, 2013 Honorable Congreso de la Nación Argentina. Repositorios digitales institucionales de acceso abierto. http://servicios.infoleg.gob.ar/infoleglnternet/anexos/220000224999/223459/norma.htm [Last accessed: 7 October 2020].

Maloberti, M., Di Lullo, E. and Gramajo Bühler, M. 2019 'El Colegio de Profesionales en Arqueología de Tucumán (CPAT): entre la estructura legal y la práctica profesional', Práctica Arqueológica. Revista de la Asociación de Arqueólogos Profesionales de la República Argentina 2(1), 47-52. http://www.aapra.org.ar/wpcontent/uploads/2020/04/10-Maloberti-et-al.pdf

Pegoraro, A. and Spoliansky, V. 2013. 'El Archivo del Museo Etnográfico Juan B. Ambrosetti: documentos para la historia institucional y disciplinar', Revista Electrónica de Fuentes y Archivos 4(4), 180-89. https://refa.org.ar/file.php?tipo=Contenido\&id=99

Politis, G. 1992 'Política Nacional, Arqueología y Universidad en Argentina' in G. Politis (ed) Arqueología en América Latina Hoy, Bogotá: Biblioteca Banco Popular. 70-87.

Politis, G. and Curtoni, R. 2011 'Archaeology and politics in Argentina during the last 50 years' in L. Lozny (ed) Comparative Archaeologies, New York:

Springer. https://doi.org/10.1007/978-1-4419-8225-4 14 
Ratto, N. 1998 'Debate 2. Arqueología y situaciones de impacto: reflexiones sobre el caso Tafí del Lic. Carlos Aschero', Mundo de Antes 1(1), 23-

27. http://www.mundodeantes.org.ar/pdf/revista1//2\%20Ensayo\%20de\%20opinion.pdf

Ratto, N. 2010 'Arqueología y la Evaluación de Impacto Ambiental', Xama 19-23, 35776. http://proyectopacha.com.ar/wp-content/uploads/2013/06/2010-Art-Ratto-Xama.pdf

Repositorio Suquía 2020 Programa de Arqueología

Digital. https://suquia.ffyh.unc.edu.ar/handle/suquia/1 [Last accessed: 7 October 2020].

SIU-BDU2 2020 Secretaría de Políticas Universitarias, Ministerio de Ecuación, República Argentina. http://cosechador.siu.edu.ar/bdu3/ [Last accessed: 24 October 2020].

Wilkinson, M., Dumontier, M., Aalbersberg, I. et al. 2016 The FAIR Guiding Principles for scientific data management and stewardship. Scientific Data 3(1), 160018. https://doi.org/10.1038/sdata.2016.18 